\title{
First Record of Contracaecum rudolphii Hartwich, 1964 in Carassius gibelio (Bloch, 1782) From Turkey
}

\author{
Deniz İnnal $^{1}$ (D), Mala Stavrescu-Bedivan² (iD, Mehmet Oğuz Özturk ${ }^{3}$ (D), Özlem Özmen ${ }^{4}$ (i)
}

Cite this article as: Innal, D., Stavrescu-Bedivan, M., Öztürk, M. O., Özmen, Ö. (2020). First record of Contracaecum rudolphii Hartwich, 1964 in Carassius gibelio (Bloch, 1782) from Turkey. Aquatic Sciences and Engineering, 35(1), 1-5.

ORCID IDs of the authors: D.i. $0000-0002-1686-0959$ M.S.B. $0000-0001-9825-417 \mathrm{X}$ M.O.Ö. 0000-0001-7263-3585 Ö.ö. 0000-0002-1835-1082

'Burdur Mehmet Akif Ersoy University, Department of Biology, Burdur, Turkey

${ }^{2}$ University of Agronomic Sciences and Veterinary Medicine of

Bucharest, Faculty of Agriculture, Romania

${ }^{3}$ Afyon Kocatepe University, Department of Molecular Biology and Genetics, Afyonkarahisar, Turkey

${ }^{4}$ Burdur Mehmet Akif Ersoy University, Faculty of Veterinary Medicine, Department of

Pathology, Burdur, Turkey

Submitted:

16.05.2019

Revision Requested:

09.07.2019

Last Revision Received:

19.09.2019

Accepted:

28.09.2019

Online published:

30.10.2019

Correspondence:

Deniz İnnal

E-mail:

innald@gmail.com

(C) Copyright 2020 by Aquatic

Sciences and Engineering

Available online at

https://dergipark.org.tr/ase

\section{ABSTRACT}

Thirty-eight individuals of Prussian carp, Carassius gibelio (Bloch, 1782) were collected from Karataş Lake, Burdur-Turkey and analyzed for parasite fauna. We found the nematode larvae of Contracaecum rudolphii Hartwich, 1964 in one sample (prevalence 2.63\%, mean intensity of infestation 27 parasites per fish). The individual parasite was found around the pancreas, fibrous connective tissue and its mesentery. To our knowledge, this is the first record of anisakid nematode, Contracaecum rudolphii in Turkey. Therefore, a new locality has been added to the geographical distribution of the parasite species. Furthermore, slight to severe inflammatory cells were seen on the infected tissue. Granulomatous reaction characterized by mononuclear cells and fibrous tissue proliferations were also seen around the parasite located areas.

Keywords: Nematoda, Anisakidae, first record, histopathology

\section{INTRODUCTION}

The nematodes of the genus Contracaecum belonging to the family Anisakidae are able to infect both terrestrial and aquatic animals (Shamsi, 2019). The cosmopolitan Contracaecum rudolphii Hartwich, 1964 has a complex life cycle, involving invertebrates such as copepods, ostracods or gammarids as first intermediate hosts, teleost fish as second intermediate or paratenic host and piscivorous birds e.g. cormorants as final hosts (Bartlett, 1996; Dziekońska-Rynko, Rokicki, Mierzejewska, Wziątek, \& Bielecki, 2013).

As far as we know, the first-stage larva formed in the embryonated eggs released with the faeces of definitive host moult to the second-stage, a variety of organisms including mollusks and crustaceans being able to eat eggs or larvae of Contracaecum parasites (Shamsi, 2019). Fish play the role of common hosts for the third larval stage after ingesting the already infested invertebrates (Dziekońska-Rynko \& Rokicki, 2007).
Infections of cyprinids under laboratory conditions have been proved by various authors that found nematode three-stage nematode larvae encysted in the intestinal wall or located in the internal organs of the fish (Moravec, 2009; Dziekońska-Rynko et al., 2013).

At the adult stage, C. rudolphii sensu lato (s.l.) is a parasite common in fish-eating birds such as great cormorant, Phalacrocorax carbo (Szostakowska \& Fagerholm, 2007; Al-Moussawi, 2017). Dziekońska-Rynko, Rokicki, \& Wziątek B (2008) suggested that nematodes prefer to develop in warm water bodies when cormorants become infected during their wintering season.

In Turkey, the first case of intense infection with adult Contracaecum sp. in a piscivorous bird was reported by Girişgin, Alasonyalilar-Demirer, \& Girişgin (2012) during the necropsy of the Dalmatian pelican, Pelecanus crispus. So far, larval forms of Contracaecum sp. were confirmed in the helminthofauna of several fish species from Turkey: Alburnus alburnus, Barbus 
lacerta, B. plebejus escherichi, Carassius auratus, C. carassius, Capoeta tinca, Scardinius erythrophthalmus, Rutilus rutilus and Vimba vimba (Koyun \& Altunel, 2007; Selver, Aydogdu, \& Cirak 2009; Koyun, Ulupınar, \& Gül, 2015). Moreover, larvae of Contracaecum sp. were mentioned for the first time in 2016 in the intestine of Carassius gibelio from Marmara Lake, western Turkey (Demir \& Karakişi, 2016). Nevertheless, there is still no information upon larvae of Contracaecum rudolphii parasitizing fish species in Turkey. This study describes the first case of identified C. rudolphii Hartwich, 1964 in a freshwater fish host in Turkey.

\section{MATERIALS AND METHODS}

Overall, 38 Prussian carp (Figure 1) were caught using nets by local commercial fishermen in November 2018 in Karataş Lake, Burdur. Fish speciemens were identified to species level according to Kottelat and Freyhof (2007). The individuals were transported alive to the research laboratory of Biology, Burdur Mehmet Akif Ersoy University.

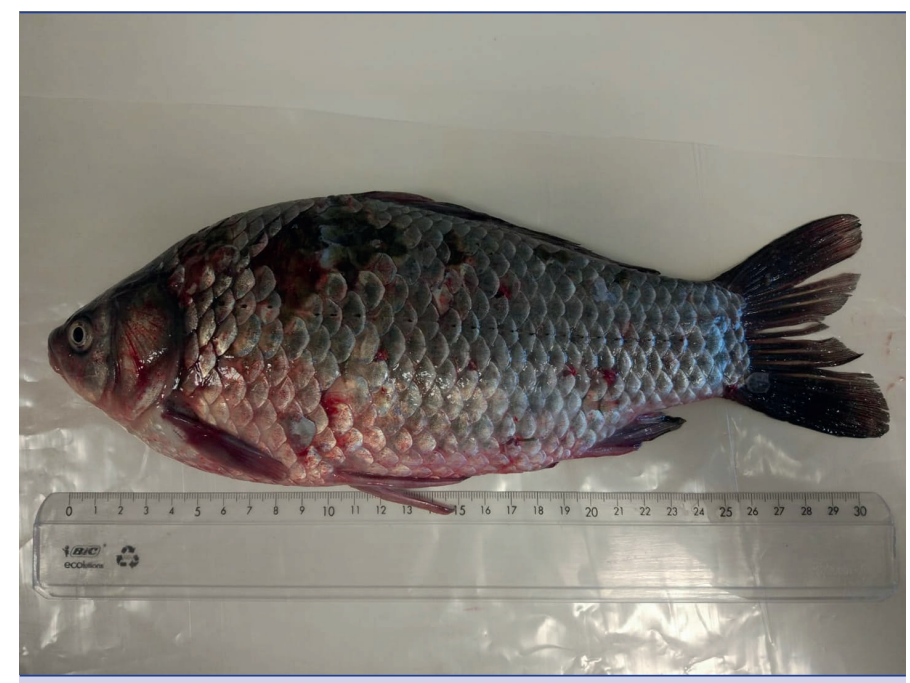

Figure 1. Carassius gibelio from Karataş Lake.

The total body length $(\mathrm{cm})$ and weight $(\mathrm{g})$ of each Carassius gibelio individuals were recorded. After all fish were sacrificed, their skin, fins, gills, oesophagus, liver, gall-bladder, stomach and intestine of the samples were dissected out and placed in petri dishes with a physiological solution. To determine the presence of parasite specimens, all parts were thoroughly examined under a binocular microscope. Parasite individuals found in the host fishes were removed using a preparation needle. The parasites were fixed in formaldehyde stained with Mayer's haematoxylin and identified using the reference keys (Pritchard \& Kruse, 1982; Anderson, 1992). The percentage of hosts infected with the parasites (prevalence, \%) and intensity were computed according to Bush, Lafferty, Lotz, \& Shostak (1997).

The gut and mesenteries samples collected from the fish during necropsy were fixed in $10 \%$ neutral formalin. The samples were then routinely prepared by automatic tissue processor equipment (Leica ASP300S, Wetzlar, Germany) and embedded in paraffin wax. Tissue sections were cut into 5 - $\mu \mathrm{m}$-thickness by a rota- ry microtome (Leica RM2155, Leica Microsystems, Wetzlar, Germany). Then, samples were stained with hematoxylin-eosin (HE), placed on a coverslip with mounting media, and examined under a light microscope.

\section{RESULTS AND DISCUSSION}

The total length of Prussian carp individuals varied between 20 and $33 \mathrm{~cm}$, while the weight values ranged between 153 and 560 grams. Among the total number of 38 specimens of Carassius gibelio examined for parasite presence, only one individual fish was infected with nematode Contracaecum rudolphii (prevalence $2.63 \%$, mean intensity of infestation 27 parasites per fish) (Figure 2).

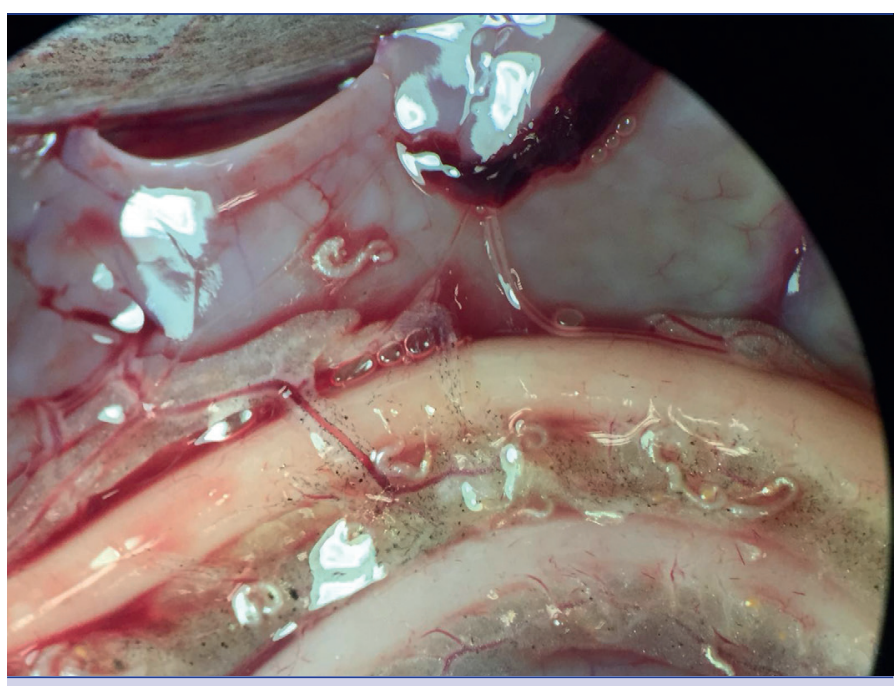

Figure 2. Contracaecum rudolphii in Carassius gibelio.

During the study, at the gross examination, hyperemias at the mesenteric vessels of infected host samples were observed. Parasites were found around the pancreas, fibrous connective tissue and its mesentery. Slight to severe inflammatory cells were seen on the infected tissue. Granulomatous reaction characterized by mononuclear cells and fibrous tissue proliferations were also seen around the located parasite areas. Some granulomas contained more than one parasite. Some granulomatous became necrotic when effected with the parasite. Numerous melano macrophages were found around the necrotic granulomas (Figure 3).

Based on genetic data evidence, Li et al. (2005) identified the existence of two-strains of the parasite, C. rudolphii-A and C. rudolphii-B. From these strains, C. rudolphii-B was determined as parasite of freshwater fishes (Szostakowska \& Fagerholm, 2007; Moravec, 2009). In the present study, the larval parasite species, C. rudolphii was identified using morphologic and anatomic features detailed by Anderson (1992), in Carassius gibelio from Karataş Lake. According to the above knowledge, the larval parasite species $C$. rudolphii determined in the present study might belong to C.rudolphii-B. In further research, DNA sequencing is obviously required in order to establish that the taxon identified in this study is C.rudolphii-B. 


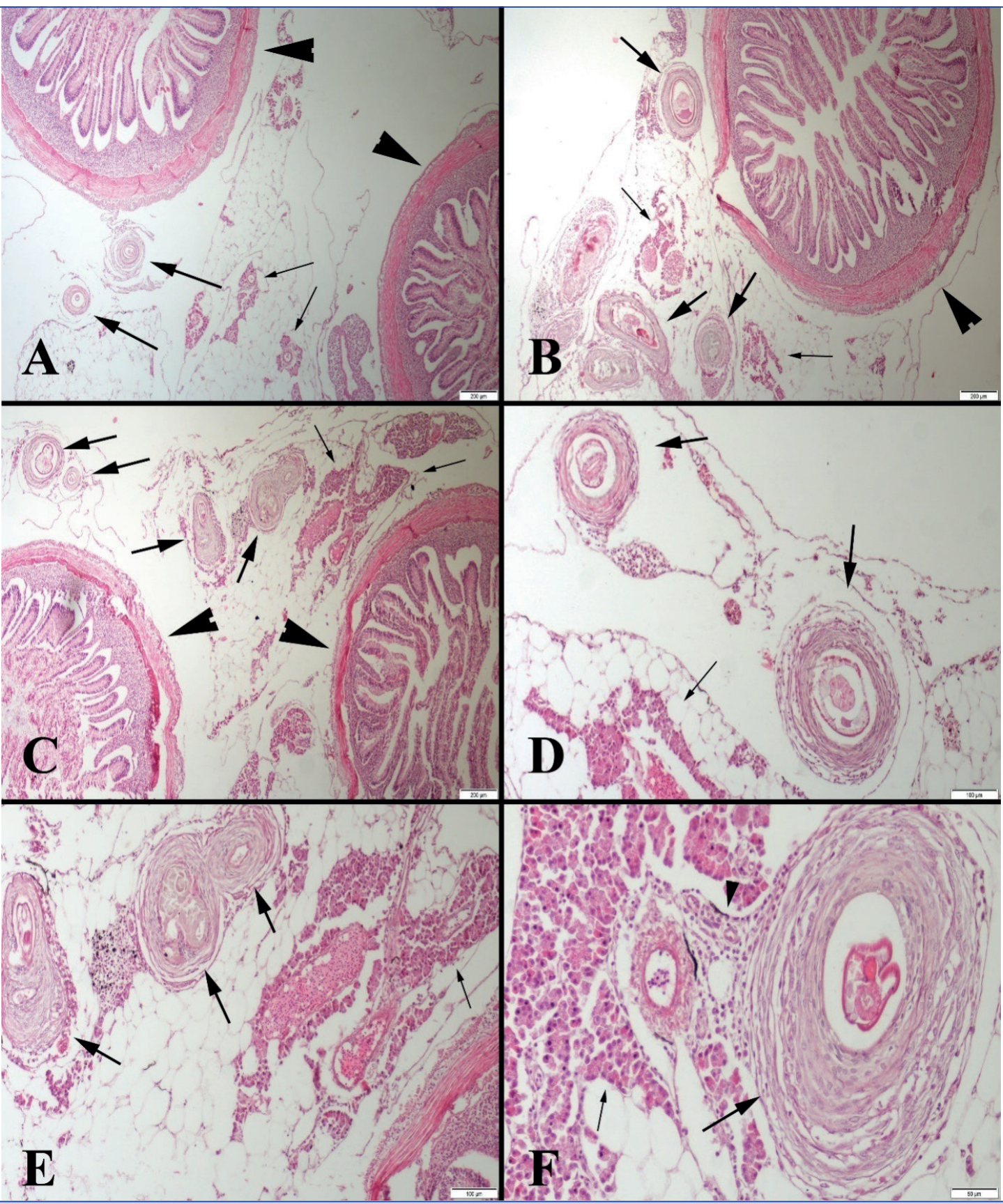

Figure 3. (A) Numerous parasites (thick arrows) localized at mesentery of the intestine (arrow heads) near the pancreas (thin arrows), HE, Bar= 200 $\mathrm{mm}$. (B) Another area and numerous parasite (thick arrows) around the intestine (arrow heads) and the pancreas (thin arrows), HE, Bar $=200 \mu \mathrm{m}$. (C) Parasites (thick arrows), near the gut (arrow heads) and pancreas (thin arrows), HE, Bar $=200 \mu \mathrm{m}$. (D-E) Higher magnification of the parasites (thick arrows), near the pancreas (thin arrows), HE, Bar=100 $\mu \mathrm{m}$. (F) Fibrous connective tissue (arrow) around the parasite and inflammatory cell infiltrations (arrow head), $\mathrm{HE}, \mathrm{Bar}=50 \mu \mathrm{m}$.

To date, another taxon, Contracaecum microcephalum was recorded for the Prussian carp from Srebarna Nature Reserve, Bulgaria (Shukerova, 2005). Different pervalence values of Contracaecum infection were reported from fish species (Stoyanov, Mutafchiev, Pankov, \& Georgiev, 2017; Oztürk \& Yesil, 2018; Dziekońska-Rynko, Mierzejewska, Kubiak, Rydzewska, \& Hliwa, 2018;
Chunchukova \& Kirin, 2018; Sokolova et al., 2018). Low values of prevalence for Contracaecum infection in fish host in the present research are consistent with other studies (Mancini et al., 2008; Roumbedakis et al., 2013; Stoyanov et al., 2017). This might be explained by reduced feeding activity of infested fish by copepods at low temperatures in the cold season (Barson, 2004). 
Similar changes were noticed by Dezfuli et al. (2016) in intestinal walls of Anguilla anguilla. In gastrointestinal tract of great cormorant Phalacrocorax carbo, Rokicki, Sołtysiak, Dziekońska-Rynko, \& Borucińska (2011) reported C. rudolphii causing lesions consisted of severe or diffuse gastritis. Larval stages of nematodes forming ulcerative eosinophilic granulomas have been found by Amato, Monteiro, \& Amato (2006) in the proventriculus of Phalacrocorax brasilianus.

Li et al. (2005) have postulated that C. rudolphii-A and C. rudolphii-B were not related with human anisakidosis, although these two sibling species have shown a zoonotic potential due to larval development in numerous fishes.

In conclusion, Contracaecum rudolphii is recorded for the first time in Carassius gibelio from Turkey. Accordingly, a new locality has been added to the geographical distribution of the parasite species. Also, hyperemia and necrotic granulomas caused by the parasite species were determined.

Acknowledgement: The authors are grateful to students Enes Faruk Malpınar, Furkan İçinata, Fahrettin Burak Kazancı, Damla Çelikkaya from Biology Department of Mehmet Akif Ersoy University for their valuable technical assistance in the course of fieldwork and laboratory studies.

\section{REFERENCES}

Al-Moussawi, A. A. (2017). Insights at morphological features of Contracaecum rudolphii Hartwich, 1964 (Nematoda: Anisakidae) as revealed by scanning electron microscope (SEM). Journalof Entomology and Zoology Studies, 5(3), 116-119.

Amato, J. F. R., Monteiro, C. M. \& Amato, S. B. (2006). Contracaecum rudolphii Hartwich (Nematoda, Anisakidae) from the Neotropical Cormorant, Phalacrocorax brasilianus (Gmelin) (Aves, Phalacrocoracidae) in southern Brazil. Revista Brasileira de Zoologia, 23(4), 1284-1289. [CrosRef]

Anderson, R.C. (1992). Nematode parasites of vertabrates, their development and transmission, CAB International, Wallingford Oxon OX 108 DE UK. $578 p$

Barson, M. (2004). The occurrence of Contracaecum sp. larvae (Nematoda: Anisakidae) in the catfish Clarias gariepinus (Burchell) from Lake Chivero, Zimbabwe. Onderstepoort Journal of Veterinary Research, 71, 35-39. [CrosRef]

Bartlett, C. M. (1996). Morphogenesis of Contracaecum rudolphii (Nematoda: Ascaridoidea), a parasite of fish-eating birds, in its copepod precursor and fish intermediate hosts. Parasite, 4, 367-376. [CrosRef]

Bush, A. O., Lafferty, K. D., Lotz, J. M. \& Shostak, A. W. (1997). Parasitology meets ecology on its own terms: Margolis et al. revisited. Journal of Parasitology, 83, 575-583. [CrosRef]

Chunchukova, M. \& Kirin, D. (2018). New data on endohelminth communities of barbel Barbus barbus from the Bulgarian part of the River Danube. Helminthologia, 55(3), 222-229. [CrosRef]

Demir, S. \& Karakişi, H. (2016). Metazoan parasite fauna of the Prussian carp, Carassius gibelio (Bloch, 1782) (Cyprinidae), from Marmara Lake, Turkey. Acta Zoologica Bulgarica, 68(2), 265-268.

Dezfuli, B. S., Manera, M., Bosi, G., DePasquale, J. A., D’Amelio, S., Castaldelli, G. \& Giari, L. (2016). Anguilla anguilla intestinal immune response to natural infection with Contracaecum rudolphii a larvae. Journal of Fish Diseases, 39(10), 1187-1200. [CrosRef]
Dziekońska-Rynko, J. \& Rokicki, J. (2007). Life cycle of the nematode Contracaecum rudolphii Hartwig, 1964 (sensulato) from northern Poland under laboratory conditions. Helminthologia, 44(3), 95-102. [CrosRef]

Dziekońska-Rynko, J., Rokicki, J. \& Wziątek, B. (2008). Experimental infection of Carassius auratus (L., 1758) with the second stage larvae of the nematode Contracaecum rudolphii Hartwich, 1964. Wiadomoœci Parazytologiczne, 54(4), 339-341.

Dziekońska-Rynko, J., Rokicki, J., Mierzejewska, K., Wziątek, B. \& Bielecki, A. (2013). Location and development of larvae of Contracaecum rudolphii Hartwich, 1964 (Nematoda: Anisakidae) in experimentally infected asps Leuciscus aspius (Linnaeus, 1758) (Pisces: Cyprinidae). Oceanological and Hydrobiological Studies. International Journal of Oceanography and Hydrobiology, 42(3), 296-301. [CrosRef]

Dziekońska-Rynko, J., Mierzejewska, K., Kubiak, K., Rydzewska, M. \& Hliwa, P. (2018). Helminths of European smelt Osmerus eperlanus (Linnaeus, 1758) in Lake Hańcza and the Vistula Lagoon, with special regard to their zoonotic threats. Acta Veterinaria Hungarica, 66(1), 96-106. [CrosRef]

Girişgin, A. O., Alasonyalilar-Demirer, A. \& Girişgin, O. A. (2012). Case of Contracaecum sp. (Ascaridida: Anisakidae) Infection in Dalmatian Pelican (Pelecanus crispus). Journal of the Faculty of Veterinary Medicine, Kafkas University, 18(Suppl-A), A227-A229.

Kottelat, M. Freyhof, J. (2007). Handbook of European freshwater fishes. Kottelat, Cornol, Switzerland and Freyhof, Berlin, Germany, 646 p.

Koyun, M. \& Altunel, F. N. (2007). Metazoon parasites of bleak (Alburnus alburnus), crucian carp (Carassius carassius) and golden carp (Carassius auratus) in Enne Dam Lake, Turkey. International Journal of Zoological Research, 1(2), 1-7.

Koyun, M., Ulupınar, M. \& Gül, A. (2015). Seasonal Distribution of Metazoan Parasites on Kura Barbell (Barbus lacerta) in Eastern Anatolia, Turkey. Pakistan Journal Zoology, 47(5), 1253-1261.

Li, A. X., D'Amelio, S., Paggi, L., He, F., Gasser, R. B., Lun, Z. R., Abollo, E., Turchetto, M. \& Zhu, X. Q. (2005). Genetic evidence for the existence of sibling species within Contracaecum rudolphii (Hartwich, 1964) and the validity of Contracaecum septentrionale (Kreis, 1955) (Nematoda: Anisakidae). Parasitology Research, 96, 361-366. [CrosRef]

Mancini, M., Bucco, C., Salinas, V., Larriestra, A., Tanzola, R. \& Guagliardo, S. (2008). Seasonal variation of parasitism in Pejerreyodontesthes bonariensis (Atheriniformes, Atherinopsidae) from la Viña Reservoir (Córdoba, Argentina). Brazilian Journal of Veterinary Parasitology, 17(1), 28-32.

Moravec F. (2009). Experimental studies on the development of Contracaecum rudolphii (Nematoda: Anisakidae) in copepod and fish paratenic hosts. Folia Parasitologia, 56(3), 185-193. [CrosRef]

Oztürk, T. \& Yesil, A, (2018). Metazoan parasite fauna of the red mullet, Mullus barbatus ponticus Essipov, 1927 in the sinop coasts of the Black Sea. Turkish Journal of Fisheries and Aquatic Sciences, 18(1), 153-160.

Pritchard, M. H. \& Kruse, G. O. W. (1982). The collection and preservation of animal parsites. Univ. Of Nebraska Press, Lincoln, U.S.A., $141 \mathrm{p}$

Rokicki, J., Sołtysiak, Z., Dziekońska-Rynko, J., \& Borucińska, J. (2011). Pathology associated with Contracaecum rudolphii (Nematoda: Anisakidae) infection in the great cormorant Phalacrocorax carbo (L. 1758). Helminthologia, 48(1), 29-35. [CrosRef]

Roumbedakis, K., Marchiori, N. C., Paseto, Á., Gonçalves, E. L. T., Luque, J. L., Cepeda, P. B., Sanches, E. G. \& Martins, M. L. (2013). Parasite fauna of wild and cultured dusky-grouper Epinephelus marginatus (Lowe, 1834) from Ubatuba, Southeastern Brazil. Brazilian Journal of Biology, 73(4), 871-878. [CrosRef] 
Aquat Sci Eng 2020; 35(1): $1-5$

İnnal, Stavrescu-Bedivan, Özturk and Özmen. First Record of Contracaecum rudolphii Hartwich, 1964 in Carassius gibelio

(Bloch, 1782) From Turkey

Selver, M., Aydogdu, A. \& Cirak, V. Y. (2009). Helminth communities of the roach (Rutilus rutilus) from Kocadere stream in Bursa, Turkey: occurrence, intensity, seasonality and their infestations linked to host fish size. Bulletin of The European Association of Fish Pathologists, 29, 131-138.

Shamsi, S. (2019). Parasite loss or parasite gain? Story of Contracaecum nematodes in antipodean waters. Parasite Epidemiol Control, 4, e00087. [CrosRef]

Shukerova, S. (2005). Helminth fauna of the Prussian carp, Carassius gibelio (Bloch, 1782), from the Srebarna Biosphere Reserve. Trakia Journal of Sciences, 3(6), 36-40.
Sokolova, M., Buchmann, K., Huwer, B., Kania, P. W., Krumme, U., Galatius, A., Hemmer-Hansen, J. \& Behrens, J. W. (2018). Spatial patterns in infection of cod Gadus morhua with the seal-associated liver worm Contracaecum osculatum from the Skagerrak to the central Baltic Sea. Marine Ecology Progress Series, 606, 105-118. [CrosRef]

Stoyanov, B., Mutafchiev, Y., Pankov, P. \& Georgiev, B. B. (2017). Helminth parasites in the alien Lepomis gibbosus (L.)(Centrarchidae) from the Lake Atanasovsko Wetlands, Bulgaria: survey of species and structure of helminth communities. Acta Zoologica Bulgarica, 69(4), 555-574.

Szostakowska, B. \& Fagerholm, H. P. (2007). Molecular Identification of Two Strains of Third-stage larvae of Contracaecum rudolphii sensulato (Nematoda: Anisakidae) from fish in Poland. Journal of Parasitology, 93(4), 961-964. [CrosRef] 